\title{
Influence of Customer Loyalty Program on Organizational Performance: a Case of Airline Industry
}

\author{
Neringa Vilkaite-Vaitone, Palmira Papsiene
}

Vilnius Gediminas Technical University

Sauletekio av. 11, LT-10223, Vilnius, Lithuania

E-mail.neringavilkaite@gmail.com, palmira.papsiene@gmail.com

cross $^{\text {ref }} \underline{\text { http://dx.doi.org/10.5755/j01.ee.27.1.10267 }}$

Loyalty programs enhance airline's value proposition. Yet little is known about how customer loyalty programs affect organizational performance. This understanding is important because airlines must decide what design of loyalty program to choose in order to maximize the revenue, profit and the number of passengers. The authors develop and test theory proposing that specific design of loyalty program ensures better organizational performance.

The purpose of this study is to examine the influence of loyalty programs on organizational performance of airlines. The methods of systemic analysis of scientific literature, secondary data analysis, comparative analysis, content analysis were used in order to reach the set purpose. Using a sample of airlines in the Baltic States, we conduct an empirical investigation of the influence of customer loyalty programs on organizational performance in airlines. The Mann-Whitney test was used to examine the differences within the organizational performance by the fact of holding a loyalty program. The results indicate that differences in loyalty programs matter. Airlines having a loyalty program can boast of a higher number of passengers carried than the ones that do not. Surprisingly no statistically significant relations were found between holding a loyalty program and airlines' revenue, profit. It follows that airlines must consider these effects before the allocation of long-term investments into customer loyalty programs.

Keywords: Customer, Loyalty, Loyalty Scheme, Loyalty Program, Reward, Airline Industry.

\section{Introduction}

Getting customers is fundamental to the success of service business, keeping customers is more important. Successful service companies recognize the relevance of cultivating loyal customers to increase sales and work to build long-term relationships with their customers through the membership in loyalty program. As a result, in highly competitive environment loyalty programs have become an increasingly common customer relationship management tool to help secure closer relationships with customers (Hutchinson et al., 2015).

Based on the realisation that it is three to five times less expensive for a business to retain its existing customers than it is to acquire new ones (Jang \& Mattila, 2005), many companies have installed loyalty programs as a core component of their marketing strategy. Airlines were the first to establish frequent flier programs. The very first program was frequent flier program AAdvantage that started in America by American Airlines in 1981 (Farooqi \& Rehmaan, 2010). Later other airlines established their own programs. Nowadays the popularity of loyalty programs is still strengthening (Omar et al., 2010; Dorotic et al., 2012). In constantly changing environment of air travel where airlines face takeovers as well as bankruptcies, loyalty programs became a solution to retain the market share. In the context of liberalization of the airline industry customer loyalty schemes are playing an increasingly important role in airlines' customer relationship management efforts. In spite that nowadays such programs are not limited to the airlines' sector, airlines remain big players and the situation in the Baltic States is not an exception. This is particularly important for major airlines in Lithuania, Latvia and Estonia (Air Lituanica, AirBaltic and Estonian Air).

Marketing researchers have studied various loyalty programmes extensively. Existing research on loyalty programs has often explored such programs on a single program in isolation (Daryanto et al., 2010; Mesa, 2013). Previous loyalty program research has considered the topic of loyalty program effects on customer behaviour (Yi \& Jeon, 2003; Lewis, 2004; Allaway et al., 2006; Lacey, 2009; Omar et al., 2010; Park, 2010; Dorotic et al., 2011; Martin et al., 2011; Agudo et al., 2012; Melnyk \& Osselaer, 2012; Shiliashki, 2013). It is widely known that customers undoubtedly like a bargain. However, it may be worth asking how rewarding loyalty programs are for the airline. This research indicates that loyalty programs provide benefits such as increased revenue, profit and number of passengers carried. Despite the extensive body of research investigating loyalty programs, little has been done to examine their ability to develop organizational performance.

Loyalty programs enhance airline's value proposition (Thompson \& Chmura, 2015). This enhancement is received by creating rewards that presumably increase switching barriers. The problem with the rewards is that they are usually costly for the airlines, while the effects on organizational performance remain unclear. Such a gap in the research field means that customer loyalty programs create dilemmas for airline managers, marketers and regulators regarding their effects on organization. Airlines 
are left unknown about the design options of loyalty programs that generate maximum revenue, profit and number of passengers.

The main objective is to examine the influence of customer loyalty programs on organizational performance. Specifically, we propose that organizational performance of the airline will vary according to the established loyalty program. Furthermore, we examine this proposition in the airline sector of the Baltic States.

Research methods used in this article are systemic analysis of scientific literature, secondary data analysis, comparative analysis, content analysis. In addition, MannWhitney test was applied for the statistical data analysis to ascertain the influence of customer loyalty program on organizational performance.

This paper relies on both theoretical and empirical analysis. In the first section, we review the literature underlying the loyalty programs, their design and influence upon the organizational performance. This analysis allows establishing the assumption of loyalty program's influence upon organizational performance on which the empirical analysis will be performed. In the second part of the paper, we prepare the methodology for the research. The third part is intended for the evaluation of loyalty programs' influence upon organizational performance in the airlines of the Baltic States. At last, the discussion and conclusions are prepared.

\section{Literature Review}

Loyalty programs are an important instrument through which service providers can increase performance effectiveness. To specify how loyalty programs effect the performance of airlines, we first thematically review the development of loyalty programs and categorize their contents.

Loyalty programs started in early 1980s. Since then loyalty programs spread widely across a variety of industries, such as hotels, book retailers, financial institutions, casinos petrol stations, car rentals and supermarkets, however the airline industry has become a mainstay.

Literature uses many terms to describe loyalty programs, including reward programmes, frequency reward programmes, frequent-shopper programmes, loyalty cards or schemes, points' cards, advantage cards and frequent flyer programmes (Dorotic et al., 2012). In this paper we adopt the term 'loyalty program' as encompassing all these terms and define loyalty program as the long-term marketing program in which customers are offered some reward based on their history of purchases (Liu \& Yang, 2009; Kim et al., 2013; Sayman \& Hoch, 2014). By focusing on long-term marketing programs, we exclude immediate benefits that are gained from promotional programs. Promotional programs do not fit into the object of the research as they are supposed to create only sudden changes in sales.

From the design perspective, a loyalty program is composed of 1) program principle, 2) reward, 3) single or multiple partners (Dorotic et al., 2012). The possible solutions for the design of loyalty program are illustrated in figure 1.
Loyalty programs might be of frequency reward or customer tier type. The first one promises a reward after the purchase of particular amount. It gives benefit to every member of loyalty program who reaches the required threshold. Customer tier loyalty program assigns customers to different segments according to their value to the firm, and may be based on actual or potential profitability (Dorotic et al., 2012).

Loyalty programs enable customers to earn rewards through their patronage of the airline. Loyalty program rewards represent a contractual obligation by the airline to the customer based upon the customer's past actions. Rewards are classified in reference to their base, type or moment of the usage. Rewards can be based upon the total amount a customer has spent at the company level or purchases made on specific items (Omar \& Musa, 2011; Dorotic et al., 2012; Zhang \& Breugelmans, 2012). The rewards of loyalty program are divided to hedonic (personalized service, entertainment, recognition by firm, social status, upgrade, priority on wait lists, individually tailored communications) or utilitarian (economic saving, gifts) (Jang \& Mattila, 2005; Dreze \& Nunes, 2009; Dorotic et al., 2012; Suh \& Yi, 2012; Meyer-Waarden \& Casteran, 2013). Management may award a favoured customer an immediate benefit or one that may be redeemed later (Jang \& Mattila, 2005; Dorotic et al., 2012; Yi \& Choi, 2013; Gaynor, 2014). According to M. Dorotic et al. (2012), when customers are not intrinsically motivated to build a relationship with a firm, they prefer immediate rewards to delayed ones, even if the immediate rewards are of less value. Immediate rewards are more effective in building a program's value than delayed rewards in low-involvement situations (Yi \& Yeon, 2003). However, Y. Liu and R. Yang (2009) state that delayed rewards in a loyalty program have a significant impact on customer loyalty, whereas one-time promotional features do not.

In reference to A. Bayraktar et al. (2010), it is not enough for companies today to use the latest technology; they should also create partnerships with other companies to offer their customers enhanced value. Single vendor loyalty programs have dominated historically, yet partnerships are becoming more prominent and are likely to increase (Dorotic et al., 2012). In airline industry partnerships are usually created with travel agencies, hotels, car rentals etc.

The major goals of a loyalty program are to establish and foster customer loyalty, provide benefit to customers by rewarding their loyalty (Dorotic et al., 2012; Evanschitzky et al., 2012; Kim et al., 2013). However, in realizing the major goals loyalty program also at least should ensure the same level of primary indicators of organizational performance.

Despite the popularity of loyalty programs, doubts about their value to the firm still exist. It is still unknown if these programs contribute to the key performance indicators in airline industry. These indicators are firm revenue, profit streams and the number of passengers carried (Gittell et al., 2004; Carlsson \& Lofgren, 2006; Lederman, 2007; Wong \& Chung, 2008; Demydyuk, 2011; Kristiani et al., 2014; Olazabal et al., 2014). 


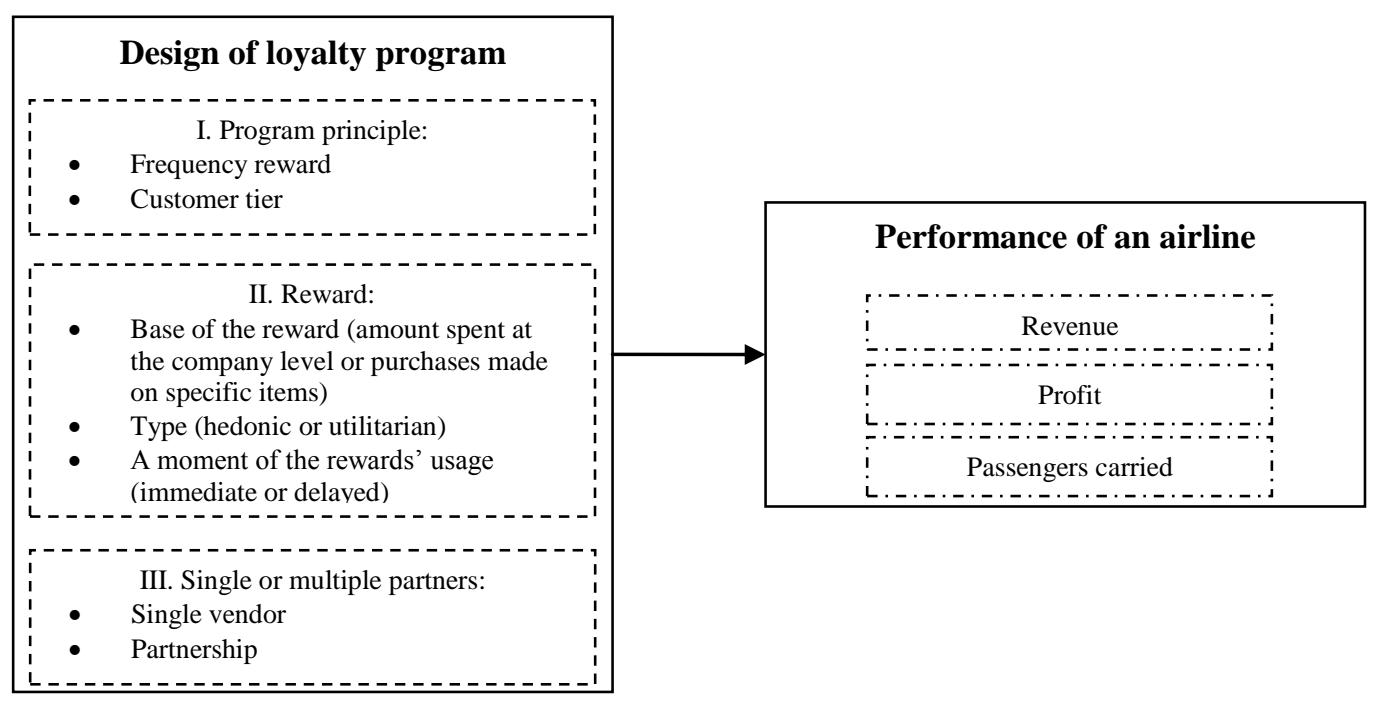

Figure 1. Conceptual framework: the effect of the design of loyalty program on organizational performance of an airline

Prior research (Berman, 2006; Bagdoniene \& Jakstaite, 2007; Liu \& Yang, 2009; Omar et al., 2010; Huettinger \& Cubrinskas, 2011; Omar et al., 2011a, 2011b) has shown that loyalty program has become an important mechanism to increase firm revenue. According to M. Dorotic et al. (2011), the effect of loyalty program on sales may depend on the volume (number of cardholders receiving the promotion), the channels of communication used or the number of featured vendors. I. Noni et al. (2014) state that loyalty program increases firm revenue by raising purchase/usage level (providing incentives for further purchases), customer satisfaction, trust and loyalty. In airline industry, huge revenue generators are frequent flyer programs (Olazabal et al., 2014). For example, American Airlines' AAdvantage program receives significant revenues from sales of miles by its hotel and car rental partners (Berman, 2006). Formally, we propose the following hypothesis:

H1: holding a loyalty program ensures a higher revenue for an airline.

Loyalty programs contribute to the profit of the company (Gilbert, 1996; Berman, 2006; Gundala, 2012; Parahoo, 2012). In reference to R. R. Gundala (2012), loyal customers add profitability to the company and the profitability of individual customers grows constantly during their relationship with the company. However, B. P. S. Murthi et al. (2011) found surprising evidence that in credit card industry customers who participate in loyalty program generate significantly less profit than those customers who do not. In airline industry the situation is opposite: frequent flyer programs do contribute to the profit of an airline (Kristiani et al., 2014). Formally, we offer the following hypothesis:

$\mathrm{H} 2$ : holding a loyalty program ensures a higher profit for an airline.

One more significant variable of organizational performance of airline companies is the number of passengers carried (Carlsson \& Lofgren, 2006; Lederman,
2007). The overall effect of enhancements to frequent flyer programs on passengers carried is negative. M. Lederman (2007) found that enhancements to frequent flyer programs shift and rotate an airline's demand curve, resulting in a new equilibrium that is characterized by a smaller number of passengers paying higher fares. However, in the United States alone frequent flyer programs have more than 80 million members (Mankin \& Jewell, 2015). Formally, we offer the following hypothesis:

H3: holding a loyalty program ensures a higher number of passengers carried.

Therefore, we theorize that loyalty program influences organizational performance (see Figure 1). The analysis of theoretical aspects of loyalty programmes indicates that such programmes offer considerable benefit to each organisation, including airlines.

\section{Research Methodology}

The aim of the research is to determine consistent patterns of causalities between customer loyalty schemes and organizational performance in the context of airline industry. Seeking to empirically substantiate the theoretical framework in the case of airline industry, the following research tasks are formulated:

1. To analyse the relation between customer loyalty programs and revenue in airline industry of the Baltic States;

2. To substantiate the existence of the relation between loyalty program and profit of airlines in the Baltic States.

3. To identify the relation between customer loyalty programs and number of passengers carried by Lithuanian, Latvian and Estonian airlines.

There is intense competition among airlines' loyalty programs because of the large number of programs offered, making it an ideal context for studying loyalty programs.

Apart from this, airlines have been one of the leading industries in the development of loyalty programs. A complete list of airlines in the Baltic States is presented in Table 1. 
In airline industry it is a normal practice to establish loyalty programs for passengers, not for cargo customers. In spite of the possibilities to implement loyalty programs for cargo customers, in this paper we dissociate from airlines that provide services of cargo flights (Airest). In addition, the complete evaluation of customer loyalty programs' influence on organizational performance has to be grounded on data about airlines' revenue, profit and passengers carried. The evaluation includes the following six airlines: Estonian air, AirBaltic, DOT LT, Avion Express, Small Planet Airlines and Air Lithuanica. For each airline we identified the launch and specifics of its loyalty program from sources such as company Web sites, public release, annual reports, loyalty programs' participation rules, business news and other public databases. At the moment of the research no data about Avies Air Company and Smartlynx was available.

Although there are multiple measures of loyalty programs, primarily we focus on the fact of holding a loyalty program. Also, the following measures of the design of loyalty program are included: program principle, base of the rewards, variety of rewards, variety of hedonic rewards, variety of utilitarian rewards, a moment of rewards' usage and partnership (Jang \& Mattila, 2005; Dreze \& Nunes, 2009; Liu \& Yang, 2009; Omar \& Musa, 2011; Dorotic et al., 2012; Suh \& Yi, 2012; Zhang \& Breugelmans, 2012; Meyer-Waarden \& Casteran, 2013; Yi \& Choi, 2013; Gaynor, 2014). Content analysis of the airlines' websites is used to frame the profiles of loyalty programs of airlines in the Baltic States. In reference to Vaskeliene and Selepen (2008), the content analysis has become a particularly popular tool of qualitative analysis enabling an objective and systematic analysis of text or other information characteristics and allowing evaluation of the level of attention given to an individual social problem or phenomenon. The empirical research of loyalty programmes applied by airlines selected website information as the unit of content analysis.

Table 1

A complete list of airlines in the Baltic States in 2015

\begin{tabular}{|c|c|c|c|c|c|}
\hline Airline & Type of flights & Country & Year established & Number of employees & Number of aircrafts \\
\hline Avies Air Company & Passenger, cargo & Estonia & 1991 & 70 & 17 \\
\hline Estonian Air & Passenger, cargo & Estonia & 1991 & 166 & 7 \\
\hline Smartlynx & Passenger, cargo & Latvia & 1993 & 140 & 10 \\
\hline AirBaltic & Passenger, cargo & Latvia & 1995 & 1200 & 21 \\
\hline Airest & Cargo & Estonia & 2001 & 1 & 1 \\
\hline DOT LT & Passenger, cargo & Lithuania & 2003 & 90 & 10 \\
\hline Avion Express & Passenger, cargo & Lithuania & 2005 & 58 & 11 \\
\hline Small Planet Airlines & Passenger, cargo & Lithuania & 2008 & 149 & 11 \\
\hline Air Lituanica & Passenger, cargo & Lithuania & 2013 & 56 & 3 \\
\hline
\end{tabular}

Organizational performance was measured by revenue, profit and passengers carried (Gittell et al., 2004; Carlsson \& Lofgren, 2006; Lederman, 2007; Wong \& Chung, 2008; Demydyuk, 2011; Kristiani et al., 2014; Olazabal et al., 2014). We use a gathered data set. The data set covers the period of 2013 and offers the opportunity to study the influence of customer loyalty program on organizational performance.

Data were analyzed using the statistical software package SPSS version 20.0. Descriptive statistics (minimum, maximum, mean and standard deviation) were applied to describe the characteristics of organizational performance of the sample. Estimation of the differences between groups (having a loyalty program or not) was conducted using Mann-Whitney tests. Decisions regarding statistical significance used $\mathrm{p}$ values below 0.05 .

\section{Results}

In order to achieve the relevant outcome from the empirical analysis we follow the assumptions that were established in previous sections. Firstly, we accomplish the content analysis of loyalty programs in separate airlines of the Baltic States. Secondly, we provide descriptive statistics for the airlines' revenue, profit and passengers carried and test the hypothesis.

The results of using loyalty program in airlines were obtained in content analysis of airlines' websites (Table 2). The empirical analysis of the loyalty programs in airline industry in the Baltic States shows that not every airline offers a customer loyalty program. The research demonstrates that only three airlines in the Baltic States (Air Lituanica, AirBaltic and Estonian Air) offer a possibility for passengers to join a loyalty program. It means that $33.33 \%$ of the airlines apply loyalty programs. Corporate program, PINS and Eurobonus are relatively similar to one another. All three programs have tiers with qualification for each tier requiring an increasing amount spent at the company level or purchases made on specific items. It seems that only base of the reward, their variety and partnership are the variables that differentiate "Air Lituanica" and "Estonian Air" from "AirBaltic". Generally, loyalty programs are characterized as frequency reward programs offering passengers' 3-24 different rewards that can be used immediately or later. 
Profiles of loyalty programs of airlines in the Baltic States

\begin{tabular}{|c|c|c|c|c|c|c|c|c|}
\hline Airline & $\begin{array}{c}\text { Title of } \\
\text { loyalty } \\
\text { program }\end{array}$ & $\begin{array}{l}\text { Program } \\
\text { principle }\end{array}$ & Base of the reward & $\begin{array}{c}\text { Variety } \\
\text { of } \\
\text { rewards }\end{array}$ & $\begin{array}{l}\text { Variety of } \\
\text { hedonic } \\
\text { rewards }\end{array}$ & $\begin{array}{c}\text { Variety of } \\
\text { utilitarian } \\
\text { rewards }\end{array}$ & $\begin{array}{c}\text { A moment } \\
\text { of rewards' } \\
\text { usage }\end{array}$ & Partnership \\
\hline $\begin{array}{l}\text { Air } \\
\text { Lituanica }\end{array}$ & $\begin{array}{l}\text { Corporate } \\
\text { program }\end{array}$ & $\begin{array}{l}\text { Frequency } \\
\text { reward }\end{array}$ & $\begin{array}{l}\text { Purchases made on specific } \\
\text { items }\end{array}$ & 3 & 0 & 3 & $\begin{array}{l}\text { Immediate, } \\
\text { delayed }\end{array}$ & No \\
\hline AirBaltic & PINS & $\begin{array}{l}\text { Frequency } \\
\text { reward }\end{array}$ & $\begin{array}{l}\text { Total amount a customer has } \\
\text { spent at the company level }\end{array}$ & 9 & 3 & 6 & $\begin{array}{l}\text { Immediate, } \\
\text { delayed }\end{array}$ & No \\
\hline $\begin{array}{l}\text { Estonian } \\
\text { Air }\end{array}$ & Eurobonus & $\begin{array}{l}\text { Frequency } \\
\text { reward }\end{array}$ & $\begin{array}{l}\text { Total amount a customer has } \\
\text { spent at the company level }\end{array}$ & 24 & 2 & 22 & $\begin{array}{l}\text { Immediate, } \\
\text { delayed }\end{array}$ & Yes \\
\hline
\end{tabular}

In order to assess if holding a loyalty program impacts airlines' revenue, profit and the number of passengers carried, data of airlines' organizational outcomes was gathered. As shown in Table 3, airlines in the Baltic States generated more than 90 million Euro revenue in 2013. The average loss in the sample was -0.24 million Euro. On average, every airline in the Baltic States carried 0.79 million passengers during 2013.

Table 3

Descriptive statistics for the airlines' revenue, profit and passengers carried

\begin{tabular}{|l|c|c|c|}
\hline \multicolumn{1}{|c|}{ Organizational outcomes } & Min & Max & Mean \\
\hline Revenue, million. Euro & 6.77 & 325.00 & 98.07 \\
\hline Profit, million. Euro & 3.72 & 9.00 & -0.24 \\
\hline Passengers carried, million passengers & 0.05 & 5.68 & 2.95 \\
\hline
\end{tabular}

Mann-Whitney tests were conducted to confirm hypothesis. The results suggest that relationship between holding a loyalty program and revenue of the airline are not statistically significant as $\mathrm{p}<0.05 \quad(\mathrm{p}=0.827)$. Statistically significant differences of profit were also not noticed between the airlines that hold a loyalty program and the ones that do not $(\mathrm{p}=0.275)$. The results demonstrate that airlines holding a loyalty program can boast of a higher number of passengers carried (mean rank=4.33) than ones that do not (mean rank=2.67), $\mathrm{p}=0.018$.

The empirical analysis of the loyalty programs impact upon organizational performance of airlines in the Baltic States let to make a conclusion that loyalty program if it works as intended has a huge potential to increase the number of passengers carried. Consequences of the loyalty program do not include the increase in revenue or profit.

\section{Discussion}

Airlines have spent millions of dollars on developing customer loyalty programs that are designed to cultivate profitable customers by offering hedonic, utilitarian rewards. However, there is considerable controversy regarding the effect of these programs in organizational performance or the airlines. Previous research has explored the impact of customer loyalty programs on organizational performance, however the findings are mixed. So it is unclear if loyalty programs can help airlines gain competitive advantage in the industry. Findings of the research in case of airlines in the Baltic States demonstrate the rationale for adopting a loyalty program and provide empirical evidence for its effect.

The research examined the influence of customer loyalty program on organizational performance. The main indicators of organizational performance in airline industry included revenue, profit and passengers carried. Hypothesis were tested by using Mann-Whitney tests. The relationship between the loyalty program and passengers carried $(\mathrm{H} 3)$ is the key finding of this study as the results were significant. The findings revealed that no significant relationship exist between loyalty program and revenue (H1) and profit (H2). Our result is consistent with Carlsson's and Lofgren's (2006) findings were the researchers refer to the number of passengers carried and suggest that airline possessing a loyalty program carries more passengers annually.

The conclusions we reached that no significant relationship exist between loyalty program and revenue, profit were somewhat contrary to the conventional wisdom and hold many lessons for marketers. However, the results can be explained by the conclusion reached by T. J. Kearney (1990) who stated that the frequent flyer program can fail, "because airlines are in the business of selling tickets, and cannot afford to give away the only product they have to sell“". Such a type of rewards might lead the airline to the decrease in revenue and profit.

The findings of our study carry some limitations. First, the sample is not a probability sample as the data was collected in one market. Conclusions should be approached with some caution as the success of airlines depends not only on the programs themselves but also on other factors, such as changes in organizational performance might be determined not only by the loyalty program, but also by changes in macroeconomic environment in the Baltic States, financial situation of the airlines, marketing programs or attractiveness of destinations.

We believe there are numerous opportunities for future research. More comprehensive set of organizational performance measures needs further investigation. Meaningful factors of organizational performance in airline might include number of routes, return on assets, return on total capitalization, passenger load factor, revenue passenger kilometres etc. Further research may examine how differences in loyalty programs affect the 
organizational performance of airlines. In addition, future research may analyse the market reaction to specific choices of loyalty programs made by airlines in the Baltic States.

\section{Conclusions}

The scientific literature analysis have shown that organizational performance of the airline is dependent upon the loyalty program and its design (program principle, rewards, partnership). The hypothesis that were raised after the scientific publication analysis were tested using Mann-Whitney test. The analysis of statistical data has shown that no significant relationships exist between loyalty program, revenue, and profit. However, loyalty program of the airline operating in the Baltic States if it works as intended has a huge potential to increase the number of passengers carried. It can be concluded that the consideration of organizational performance in airlines is very important, so the results of this research allow conceiving the consistent patterns of the relation between loyalty programs and organizational performance in airlines of the Baltic States.

Customer loyalty programs in airlines that can be specific in principle of the program, reward or partnership, are described as having a huge potential to increase organizational outcomes. The analysis of loyalty programs of airlines in the Baltic States has shown the similarities of loyalty programs in the aspects of program principle (frequency reward) and a moment of rewards' usage (immediate, delayed). The results indicated that all three programs at the moment of the research had tiers with qualification for each tier requiring an increasing amount spent at the company level or purchases made on specific items.

Although the airlines' market only in the Baltic States was examined in our paper, the findings may still be of interest to other regions. The airlines performing in the EU countries undoubtedly have to consider and predict changes of passengers carried assessing the characteristics of loyalty programs'.

A clear managerial implication is that airlines have to establish loyalty programs to increase the number of passengers carried. To be successful, loyalty programs of Lithuanian airlines should target a profitable customer segment (super customers) and discourage those customers who are less valuable.

\section{References}

Agudo, J. C., Crespo, A. H., \& Bosque, I. R. (2012). Adherence to customer loyalty programs and changes in buyer behaviour. The Service Industries Journal, 32(8), 1323-1341. http://dx.doi.org/10.1080/02642069.2010.545884

Allaway, A. W., Gooner, R. M., Berkowitz, D., \& Davis, L. (2006). Deriving and exploring behavior segments within a retail loyalty card program. European Journal of Marketing, 40(11/12), $1317-1339$. http://dx.doi.org/10.1108/03090560610702830

Bagdoniene, L., \& Jakstaite, R. (2007). Estimation of loyalty programmes from customers` point of view: cases of three retail store chains. Engineering Economics, 5(55), 51-58.

Bayraktar, A., Yilmaz, E., \& Yamak, O. (2010). Implementation of RFID technology for the differentiation of loyalty programs. Journal of Relationship Marketing, 9, 30-42. http://dx.doi.org/10.1080/15332660903551867

Berman, B. (2006). Developing an effective customer loyalty program. California Management Review, 49(1), 123-148. http://dx.doi.org/10.2307/41166374

Carlsson, F., \& Lofgren, A. (2006). Airline choice, switching costs and frequent flyer programmes. Applied Economics, 38, 1469-1475. http://dx.doi.org/10.1080/00036840500419608

Daryanto, A., Ruyter, K., Wetzels, M., \& Patterson, P. G. (2010). Service firms and customer loyalty programs: a regulatory fit perspective of reward preferences in a health club setting. Journal of the Academy of Marketing Science, 38, 604-616. http://dx.doi.org/10.1007/s11747-009-0165-x

Demydyuk, G. (2011). Optimal financial key performance indicators: evidence from the airline industry. Accounting \& Taxation, 3(2), 39-51.

Dorotic, M., Bijmolt, T. H. A., \& Verhoef, P. C. (2012). Loyalty programmes: current knowledge and research directions. International Journal of Management Reviews, 14, 217-237. http://dx.doi.org/10.1111/j.1468-2370.2011.00314.x

Dorotic, M., Fok, D., Verhoef, P. C., \& Bijmolt, T. H. A. (2011). Do vendors benefit from promotions in a multi-vendor loyalty program? Marketing Letters, 22, 341-356.

Dreze, X., \& Nunes, J. C. (2009). Feeling superior: the impact of loyalty program structure on consumers' perceptions of status. Journal of Consumer Research, 35, 890-905. http://dx.doi.org/10.1086/593946

Evanschitzky, H., Ramaseshan, B., Woisetschlager, D. M., Richelsen, V., Blut, M., \& Backhaus, C. (2012). Consequences of customer loyalty to the loyalty program and to the company. Journal of the Academy of Marketing Science, 40, 625-638. http://dx.doi.org/10.1007/s11747-011-0272-3

Farooqi, R., \& Rehmaan, A. (2010). A comparison of loyalty programs of two lifestyle retail stores using the net-promoter score method. Pranjana, 13(2), 38-46.

Gaynor, G. B. (2014). Accounting techniques for loyalty programs and promotional allowances in the gaming industry. Academy of Accounting and Financial Studies Journal, 18(2), 77-91. 
Gilbert, D. C. (1996). Relationship marketing and airline loyalty schemes. Tourism Management, 17(8), 575-582. http://dx.doi.org/10.1016/S0261-5177(96)00078-7

Gittell, J. H., Nordenflycht, A., \& Kochan, T. A. (2004). Mutual gains or zero sum? Labor relations and firm performance in the airline industry. Industrial and Labor Relations Review, 57(2), $163-180$. http://dx.doi.org/10.1177/001979390405700201

Gundala, R. R., Jack, A. L., \& Gomes, R. R. (2012). Do loyalty schemes really create loyalty? Evidence from Trinidad's supermarket retail sector. International Journal of Business, Marketing and Decision Sciences, 5(2), 35-50.

Huettinger, M., \& Cubrinskas, V. (2011). Unmanned bonds: the impact of self-automated service on consumer loyalty. Engineering Economics, 22(2), 203-213. http://dx.doi.org/10.5755/j01.ee.22.2.317

Hutchinson, K., Donnell, L. V., Gilmore, A., \& Reid, A. (2015). Loyalty card adoption in SME retailers: the impact upon marketing management. European Journal of Marketing, 49(3/4), 467-490. http://dx.doi.org/10.1108/EJM-06-20130321

Jang, D., \& Mattila, A. S. (2005). An examination of restaurant loyalty programs: what kinds of rewards do customer prefer? International Journal of Contemporary Hospitality Management, 17(5), $402-408$. http://dx.doi.org/10.1108/09596110510604823

Kearney, T. J. (1990). Frequent flyer programs: a failure in competitive strategy, with lessons for management. Journal of Consumer Marketing, 7(1), 31-40. http://dx.doi.org/10.1108/EUM0000000002567

Kim, H. Y., Lee, J. Y., Choi, D., Wu, J., \& Johnson, K. K. P. (2013). Perceived benefits of retail loyalty programs: their effects on program loyalty and customer loyalty. Journal of Relationship Marketing, 12, 95-113. http://dx.doi.org/10.1080/15332667.2013.794100

Kristiani, E., Sumarwan, U., Yuliati, L. N., \& Saefuddin, A. (2014). The role of relational reward benefits for developing the non-financial value of a customer to an organization: structural equation modeling approach. Gadjah Mada International Journal of Business, 16(2), 111-142.

Lacey, R. (2009). Limited influence of loyalty program membership on relational outcomes. Journal of Consumer Marketing, 26(6), 392-402. http://dx.doi.org/10.1108/07363760910988210

Lederman, M. (2007). Do enhancements to loyalty programs affect demand? The impact of international frequent flyer partnerships on domestic airline demand. RAND Journal of Economics, 38(4), 1134-1158. http://dx.doi.org/10.1111/j.0741-6261.2007.00129.x

Lewis, M. (2004). The influence of loyalty programs and short-term promotions on customer retention. Journal of Marketing Research, 41(3), 281-292. http://dx.doi.org/10.1509/jmkr.41.3.281.35986

Lima, L. I., \& Neto, P. J. S. (2013). Understanding of loyalty programs' participation rules. Review of Business Management, 15(49), 489-503. http://dx.doi.org/10.7819/rbgn.v15i49.1410

Liu, Y., \& Yang, R. (2009). Competing loyalty programs: impact of market saturation, market share, and category expandibility. Journal of Marketing, 73, 93-108. http://dx.doi.org/10.1509/jmkg.73.1.93

Mankin, J. A., \& Jewell, J. J. (2015). Frequent flyer miles as a company scrip: implications on taxation. Business Studies Journal, 7(1), 14-32.

Martin, J. C., Roman, C., \& Espino, R. (2011). Evaluating frequent flyer programs from the air passengers' perspective. Journal of Air Transport Management, 17(6), 364-368.

Melnyk, V., \& Osselaer, S. M. J. (2012). Make me special: gender differences in consumers“ responses to loyalty programs. Marketing Letters, 23, 545-559. http://dx.doi.org/10.1007/s11002-011-9160-3

Mesa, F. E. (2013). A cur from above: the impact of loyalty program status on member's behavior. DLSU Business \& Economic Review, 23(1), 1-9.

Meyer-Waarden, L., \& Casteran, C. B. H. (2013). The effects of purchase orientations on perceived loyalty programmes' benefits and loyalty. International Journal of Retail \& Distribution Management, 41(3), $201-225$. http://dx.doi.org/10.1108/09590551311306255

Murthi, B. P. S., Steffes, E. M., \& Rasheed, A. A. (2011) What price loyalty? A fresh look at loyalty programs in the credit card industry. Journal of Financial Services Marketing, 16(1), 5-13. http://dx.doi.org/10.1057/fsm.2011.3

Noni, I., Orsi, L., \& Zanderighi, L. (2014). Coalition loyalty-programme adoption and urban commercial-network effectiveness evaluation. International Journal of Retail \& Distribution Management, 42(9), 818-838. http://dx.doi.org/10.1108/IJRDM-05-2012-0043

Olazabal, A. M., Marmorstein, H., \& Sarel, D. (2014). Frequent flyer programs: empirically assessing consumers' reasonable expectations. American Business Law Journal, 51(1), 175-250. http://dx.doi.org/10.1111/ablj.12026

Omar, N. A., \& Musa, R. (2011). Measuring service quality in retail loyalty programmes (LPSQual). International Journal of Retail \& Distribution Management, 39(10), 759-784. http://dx.doi.org/10.1108/09590551111162257 
Omar, N. A., Alam, S. S., Aziz, N. A., \& Nazri, M. A. (2011a). Retail loyalty programs in Malaysia: the relationship of equity, value, satisfaction, trust and loyalty among cardholders. Journal of Business Economics and Management, 12(2), 332-352. http://dx.doi.org/10.3846/16111699.2011.573297

Omar, N. A., Aziz, N. A., \& Nazri, M. A. (2011b). Understanding the relationships of program satisfaction, program loyalty and store loyalty among cardholders of loyalty programs. Asian Academy of Management Journal, 16(1), 2141.

Omar, N. A., Wel, C. A. C., Musa, R., \& Nazri, M. A. (2010). Program benefits, satisfaction and loyalty in retail loyalty program: exploring the roles of program trust and program commitment. The IUP Journal of Marketing Management, 9(4), 6-28.

Parahoo, S. K. (2012). Motivating shoppers to come back: modeling consumer behaviour in retailer loyalty programs. Issues of business and law, 4, 106-118. http://dx.doi.org/10.5200/ibl.2012.10

Park, J. W. (2010). The effect of frequent flyer programs: a case study of the Korean airline industry. Journal of Air Transport Management, 16(5), 287-288. http://dx.doi.org/10.1016/j.jairtraman.2010.02.007

Sayman, S., \& Hoch, S. J. (2014). Dynamics of price premiums in loyalty programs. European Journal of Marketing, 48(3/4), 617-640. http://dx.doi.org/10.1108/EJM-11-2011-0650

Shiliashki, M. (2013). The untapped potential of digital loyalty programmes. Journal of Payments Strategy \& Systems, $7(2), 106-111$.

Suh, J. C., \& Yi, Y. (2012). Do consumption goals matter? The effects of online loyalty programs in the satisfactionloyalty relation. Psychology \& Marketing, 29(8), 549-557. http://dx.doi.org/10.1002/mar.20542

Thompson, F. M., \& Chmura, T. (2015). Loyalty programs in emerging and developed markets: the impact of cultural values on loyalty program choice. Journal of International Marketing, 23(3), 87-103. http://dx.doi.org/10.1509/jim.14.0125

Vaskeliene, L., \& Selepen, J. (2008). Informacijos apie intelektini kapitala atskleidimas Lietuvos akcinese bendrovese. Ekonomika ir vadyba, 13, 88-97.

Wong, J. Y., \& Chung, P. H. (2008). Retaining passenger loyalty through data mining: a case study of Taiwanese airlines. Transportation Journal, 47(1), 17-29.

Yi, Y., \& Choi, J. B. (2013). Segregation vs aggregation in the loyalty program: the role of perceived uncertainty. European Journal of Marketing, 47(8), 1238-1255. http://dx.doi.org/10.1108/03090561311324309

Yi, Y., \& Jeon, H. (2003). Effects of loyalty programs on value perception, program loyalty, and brand loyalty. Journal of the Academy of Marketing Science, 31, 229-240. http://dx.doi.org/10.1177/0092070303031003002

Zhang, J., \& Breugelmans, E. (2012). The impact of an item-based loyalty program on consumer purchase behavior. Journal of Marketing Research, 49, 50-65. http://dx.doi.org/10.1509/jmr.09.0211

The article has been reviewed.

Received in March 2015; accepted in February, 2016. 